\title{
Collaborative Governance in Household Handling
}

\author{
Abdul Sabaruddin ${ }^{1}$, Achmad Lamo Said ${ }^{2}$ \\ ${ }^{1}$ Faculty Of Social Sciences and Political Sciences, \\ University of Sembilanbelas November Kolaka, Indonesia, \\ ${ }^{2}$ Faculty Of Social Sciences and Political Sciences, \\ University of Sembilanbelas November Kolaka, Indonesia,
}

\begin{abstract}
:
This study will examine and analyze collaborative governance processes as the basis for the formation of collaboration and the factors that influence collaborative governance in the handling of uninhabitable house. The research method used is a qualitative approach and the type of research is action research, known as participatory action research (PAR). Basically, PAR is a research that actively involves all relevant parties (stakeholders) in assessing actions or interactions between organizations in order to make changes and improvements in a better direction. Data collection is done by participant observation, interviews, and document search. Data analysis technique is an interactive analysis which includes the stages of data reduction, data presentation and data verification / drawing conclusions.

Moreover, the results of the study, the process of collaborative governance in the handling of uninhabitable houses in Kolaka and North Kolaka Districts was carried out through formal mechanisms and informants, including (1) dialogue between actors: the stage of formal and informal dialogue between actors. Formally, the dialogue was through a joint forum by forming housing and settlement areas (POKJA PKP). While not formally planning and implementing the handling of uninhabitable houses puts forward deliberation (2) builds consensus: the actors involved have responsibilities that have been decided together. Furthermore, the regional government prepares the budget through the APBD and the Housing and Settlements Agency as the executor and the person in charge of the program. The village / kelurahan government is involved in data collection and verification of uninhabitable houses. The private sector is involved in the supply of building materials and the community participates in the form of willingness to become labor and readiness to provide materials. (3) commitment to goals: this phase describes the recognition of actors involved in collaboration to be responsible for solving public problems. The realization of this commitment is the implementation of the program with a participatory approach. Meanwhile, the factors that influence collaborative governance are: (1) leadership, (2) communication, (3) commitment, and (4) common vision.
\end{abstract}

Keywords: Collaborative Governance and Unworthy Homes

\section{Introduction}

Housing is one of the basic human needs. Besides, the condition of healthy and habitable housing is everyone's dream. However, the economic limitations of the community are the cause of the non-fulfillment or limited access to housing needs that are suitable for some people. The limitations of the poor in accessing healthy and decent homes are important things that need to be considered by the government.

Collaboration is one option in solving government limitations in aspects of resources such as information, finance, technology and employees. Foslen (2002) in Dwiyanto (2010) explains that the concept of collaboration involves intensive collaboration between parties, including conscious efforts to align in goals, strategies, agendas, resources and activities. Bryson, Crosby and Stone (2006) describe collaboration as a network or distribution of information, resources, activities and capabilities of organizations in two or more sectors to work together to achieve a goal that cannot be achieved if working individually.

Moreover, various descriptions of research results on forms of collaboration show the existence of complex problems including the blurring of boundaries of inter-sector cooperation, the basic nature of network relations which hopes greater than public managers to collaborate both between themselves and across sectoral boundaries. The results of other empirical research also show that 
collaboration is considered a necessity but still requires attention related to collaborative approaches. This happens because there are still few studies that examine the failure of collaboration and sectoral collaboration between the public, private and community sectors or collaboration of three pillars of governance. Thus, this study will identify the process of collaborative governance in the handling uninhabitable house and what factors influence collaborative governance in the handling uninhabitable house.

\section{Literature Review}

\subsection{Collaborative concept}

Thomson \& Perry (2006) contend collaboration is a process in which stakeholders interact and negotiate, together creating rules and structures that govern their relationships and ways of acting or deciding on the issues they bring. Collaboration is a process that involves shared norms and mutually beneficial interactions.

Collaboration is comprehend as collaboration between factors, between organizations or between institutions in order to achieve goals that cannot be achieved or done independently. In Indonesian, the terms collaboration and collaboration itself are still used interchangeably and there have been no attempts to show the difference and depth meaning of the term. In general, the term collaboration is better known than collaboration, and there is no deeper understanding of what paradigm should be adopted (Sabaruddin, 2015).

Collaboration is a type of positive interaction associated with cooperative efforts, accompanied by the hope of mutual benefit (Kozuch, 2011). Referring to the relationships between organizations, these relationships include relationships that combine each organization in realizing a common goal. This is characterized by a high level of longterm interdependence. This is defined as "a relationship that is durable and brings an organization that was previously separated into a new structure with a commitment to a common mission, structure, or planning effort," (Perrault et al, 2011, in Kozuch et al, 2016).

\subsection{Collaborative Governance Concept}

Collaborative governance is one type of governance where public and private actors work together in a special way, using certain processes to establish laws and rules to determine a good public (Ansell and Gash, 2007). The concept of collaborative governance refers to a group of interdependent stakeholders, usually from various sectors, who work together to develop and implement policies to overcome complex and multifaceted problems and situations "(Choi \& Robertson, 2014 in Choi, 2014).

Ansell and Gash (2007) define collaborative governance as a set of settings in which one or more public institutions directly involve non-state stakeholders in a formal, consensus-oriented and deliberative policy-making process that aims to create or implement public policies or regulate public programs or assets.

Seigler (2011) presents eight main principles in the application of collaborative governance: (1) Citizens must be involved in the production of public goods, (2) Communities must be able to mobilize resources and assets to solve public problems, (3) professionalism must share expertise they are to empower citizens, (4) Policies must present public deliberations, (5) Policies must contain sustainable collaborative partnerships, (6) Policies must be strategic, (7) Policies must change institutions for community empowerment and public problem solving, ( 8) Policies must contain accountability.

According to Ansell and Gash (2007), collaborative governance emerged as a response to implementation failure and high costs and politicization of regulations. This was developed as an alternative adversarialism for interest group pluralism and failure of managerialism accountability (especially the expert authority challenged). More positively, one might argue that the tendency towards collaboration also arises from the development of science and institutional capacity. A knowledge becomes more specialized and distributed and the institutional infrastructure becomes more complex and interdependent, the demand for collaboration increases.

\subsection{Housing and Settlements}

The house is one type of space where people move, must be viewed from all sides of the factors that influence it and from the many factors that are central to human beings. In other words, the conception of home must refer to the main goal of humans who inhabit it with all the values and norms it adheres to (Budiharjo, 1998). The house cannot be viewed individually, because it is related and must care about its social environment, then housing is an integral part of its social system. Housing planning must be seen as a unit that is united with the surrounding environment, so there must be social spaces (shared spaces) for the community to interact with each other. The housing units are organizing the need for privacy and the need to interact socially. (Syarief, 2000).

Slum areas are often identical with the existence of poor people. This perception is not always true because in the slums there are also residents who are not categorized as poor. This is marked by the condition of the house and facilities they have in the slum area. According to Basri (2010) there are two things that characterize the area as slum, namely: (1) the area is not or less served with regional supporting infrastructure such as road networks, drainage, sewage channels, etc., so that the area tends to experience degradation; and (2) occupancy in the area can be seen visibly uninhabitable which is characterized by a lack of ventilation and lighting, in addition to the building materials that are not suitable to be used as building materials for a dwelling. (Wijaya, 2016). 


\section{RESEARCH METHODS}

In accordance with the objectives to be achieved in this study, namely the preparation of collaborative governance models in the handling of slums, this study uses a qualitative approach and the type of research is action research, known as participatory action research (PAR). Data collection techniques in this study employ techniques, namely: Observation; Deep interview; Focus group discussions; s and Documentation. The data obtained is then analyzed by organizing the data obtained into a category, describing the data into units, analyzing important data, compiling or presenting data in accordance with the research problem in the form of reports and making conclusions to be easily understood using interactive models from Miles and Huberman.

\section{Research Result}

\subsection{Collaborative Governance Process in Handling Uuninhabitable Houses}

The process of collaborative governance in handling uninhabitable houses in Kolaka and Kolaka Utara regencies includes the following stages:

\section{Identifying Obstacles and Opportunities}

The handling of uninhabitable houses in Kolaka Regency and North Kolaka begins with identification of problems faced. Collaborative governance in Kolaka and Kolaka Utara Districts was built on the basis of the government's financial limitations in financing development. The private sector and the community are involved to cooperate in solving these problems. The government, the private sector and the community work together to find solutions with the unification and utilization of the resources owned by each party. The government must be able to eliminate all constraints and limitations in the implementation of public services by mobilizing all the potential resources owned by the region. In Kolaka District, the mechanism for handling uninhabitable houses began with the establishment of a Housing and Settlement Area (POKJA PKP) working group through the Kolaka Regent Decree No. 188.45 / 307/2017. This POKJA is formed based on consideration to support government programs for the sustainable development of housing and residential areas and benefit the welfare of the community. So that the community is able to live and have a safe, healthy and sustainable habitable home.

The POKJA consists of elements from the government, private organizations, banking institutions, state-owned enterprises (BUMN), and administrators of the slum-less city program (KOTAKU). The POKJA was led directly by the head of the housing agency and the settlement area. The LWG also acts as a government partner in disseminating or communicating housing and settlement development policies (PKP) as well as the process of extracting community aspirations against plans for development of policies or development plans and settlement areas.
In addition to establishing PKP LWGs, the Kolaka District government also developed cooperation with the PT Antam Tbk UPBN Southeast Sulawesi company. This cooperation mechanism begins with the submission of letters to the company regarding program synergy between the government and the company. In the letter, it contained the wishes of the Kolaka Regency government to invite companies to participate in development.

Meanwhile, in North Kolaka Regency, the handling of uninhabitable houses is handled directly by the Department of Housing, Settlements and Defense. There is no special institution established although in accordance with technical guidelines there is an institution called the PKP working group. In addition to the Department of Housing, Settlement and Land Affairs, the handling of uninhabitable houses in North Kolaka Regency also involves the North Kolaka Regency Police Agency. The involvement of the North Kolaka District Police in the construction of uninhabitable homes as a form of concern for the poor.

\section{Debating Strategies For Influence (Dialogue Phase)}

The dialogue phase intended in this study is the stage of building communication between parties involved in handling livable houses in Kolaka and North Kolaka districts. At this stage, stakeholders involved in communicating both directly and indirectly. Direct communication is carried out in the form of meetings between stakeholders while indirect communication is carried out without directly involving the parties involved but through written communication (correspondence).

Then, in Kabupaten Kolaka Utara, the communication mechanism for handling uninhabitable housing in the form of a Self-Help Stimulation Assistance Program (BSPS) began with the submission of the Housing, Settlement and Land Affairs Office of North Kolaka Regency to the village / kelurahan government to identify uninhabitable houses.

The dialogue phase is then continued in the form of village socialization about the BSPS program. In this socialization the purpose, objectives and form of BSPS activities. The purpose of the BSPS activities is to increase the initiative of Low-Income Communities (MBR) in the development / improvement of the quality of houses along with the infrastructure, facilities and utilities. General (PSU) so as to make a healthy, safe, harmonious and orderly and sustainable housing.

\section{3) Planning Collaborative Actions (Optional Phase)}

The program for handling uninhabitable houses in Kolaka and Kolaka Utara Districts is carried out through:

1. Roof, Floor and Wall House dissection Program (ALADIN) 
The implementation of the ALADIN program is supported by an organizational structure designed by the Kolaka District government so that such a large program can be realized systematically and achieve the target according to plan. The implementation pattern is carried out in an integrated manner by involving all regional units starting from SKPD, sub-district governments to village / kelurahan administrations.

SKPD becomes a field technical implementation unit where the task is to follow up on the results of the identification of the District Coordination Team in the form of activities in accordance with their duties and functions. The results of the identification were first verified, and the results of the verification were coordinated again with the BPMD. Then an activity plan is set forth in the SKPD budget implementation document (DPA-SKPD) in each SKPD.

At the level of the sub-district government the task is to socialize the ALADIN program to the level of the village / kelurahan apparatus in their respective work areas. The Camat is tasked with facilitating the identification activities carried out by the district team, monitoring at each stage of the implementation of the ALADIN program carried out by the SKPD and reporting to the district coordination team. In addition, the sub-district head is also tasked with helping to solve problems arising in his area.

At the village / kelurahan level, the task is to assist in the preparation of proposed activities as a follow up to the results of the identification of the district team, knowing the proposed activities to be carried out in the work area, motivating the community to participate in activities carried out by the SKPD, and receiving facilities and infrastructure resulting from the activities of the SKPD after it is stated that the work has been completed by the district team to be managed by a community group.

The strategy adopted so that the entire ALADIN program is achieved is to embrace the principle of cohesiveness, where each sector conducts a plan which is then carried out with the value of participation / community self-help of at least $40 \%$ carried out by mutual cooperation. The government is tasked with preparing heavy equipment and stimulant assistance from shop owners and the community prepares the material. Because the programs that have been planned are the main tasks of the SKPD, the financing is charged to each SKPD and other legitimate sources. Financing from the SKPD only functions as a stimulant in order to provoke community participation so that the scale of financing of each activity is $60 \%$ of the government and $40 \%$ of the community / private sector.

\section{Self-help Housing Stimulation Assistance Program (BSPS)}

The implementation of the Self-Help Housing Stimulation Program (BSPS) is a program to realize livable houses that are supported by infrastructure, facilities and public utilities so as to make housing healthy, safe, harmonious, and orderly and sustainable. The implementation of BSPS is carried out with the principle of community self-reliance, and community empowerment. Assistance from the Government is stimulant in order to improve the quality of houses and the new construction of houses to be suitable for habitation, including the quality of housing eligibility so that it can be inhabited requires commitment and readiness of the community in the form of self-help funds in the form of savings in building materials and other assets or savings that can be used as additional funds.

In Kolaka Regency, the collaboration process in handling uninhabitable houses is carried out based on mutual agreement through formal organizations, namely housing and residential areas (POKJA PKP). The establishment of the PKP Working Group is carried out through coordination meetings by inviting all stakeholders related to the Housing and Settlement Area. The establishment of PKP LWG is intended as a container or suggestion in coordinating and synergizing the implementation of housing and settlement areas in Kolaka Regency

The Kolaka District PKP Working Group set three fields of activity namely, 1) spatial planning, agrarian and land affairs, 2) basic infrastructure and housing and settlement development, 3) community empowerment, law and partnership. The organizational structure of the PKP POKJA is: (1) Government Elements: Housing and Settlements Agency, Kolaka District National Land Agency, Kolaka Regency Statistics Center, Environmental Service Agency, Licensing Agency, One Stop Service and Investment, Health Service, Community Empowerment Service, Research and Development Agency, Bappeda, and BPKAD; (2) Private Elements: Regional Water Company (PDAM), Real Estate Indonesia (REI) Kolaka Regency, Association of Housing and Settlements Developers throughout Indonesia (APERSI) Kolaka Regency, Kolaka Branch Southeast Bank, (3) Community Elements: Facilitator of KOTAKU (City Without slums).

Meanhile in Kabupaten Kolaka Utara, collaboration on handling uninhabitable houses is done informally. Collaboration does not take place in formal organizations but collaboration is based on consensus (mutual agreement). Handling of uninhabitable houses in North Kolaka Regency is the responsibility of the Department of Housing, Settlements and Land Affairs. The Office of Housing, Settlements and Land Affairs is responsible for making decisions, actions and coordination with relevant institutions / agencies and non-governmental institutions in the implementation of housing and settlement areas.

Based on the description of collaborative governance in handling of uninhabitable houses through the BSPS program in Kolaka and North Kolaka, it can be formulated that collaborative governance is a strategy in governance to address public problems that emphasize cooperation between government and non-government actors. The collaboration is carried out in a formal and non- 
formal framework based on trust and commitment in the decision making process.

Commitment to goals is an important element in realizing the implementation of the management of uninhabitable houses in Kolaka and North Kolaka Districts. The intended purpose is the establishment of decent housing by Low-Income Communities (MBR). Collaboration that occurs in the handling of uninhabitable houses in Kolaka and North Kolaka regencies is based on the commitment of the government, the community and the private sector to be responsible in realizing livable houses. The division of authority and responsibility is based on consensus (mutual agreement) according to the role of each actor. The government and the private sector are responsible for providing the budget. While community involvement is shown by participating in activities. Communities that do not participate in the implementation of the program will be canceled and given to other prospective recipients who are ready to participate.

Based on the findings of the study, the collaborative governance process in handling uninhabitable houses in Kolaka and Kolaka Utara Districts was carried out in three stages, namely dialogue between actors, consensus building and commitment to goals.

\section{Dialogue between actors}

At this stage it is interpreted as a form of communication between actors on certain issues. This dialogue aims to unite understanding and formulate the division of labor and responsibility of each actor in solving public problems. Based on the findings of the study, the stage of dialogue between actors in the handling of uninhabitable houses in Kolaka Regency was carried out through a joint forum by forming housing and settlement areas (POKJA PKP). This forum is a forum for discussion between actors in the preparation of planning and implementation of inadequate housing management through the self-help housing assistance program (BSPS). While in North Kolaka Regency, collaboration between actors in handling uninhabitable houses is carried out informally. Planning and implementation of uninhabitable housing management programs prioritize deliberation, thereby eliminating bureaucratic structures and procedures.

The presence of LWGs in the handling of uninhabitable houses in Kolaka Regency has resulted in a procedural and formal management mechanism for the implementation of improper housing. This situation provides an opportunity for the parties involved to know information about the obligations of each party in the handling of uninhabitable houses. So that each party that collaborates easily controls or oversees the implementation of the service.

\section{Building Consensus}

The actors involved in handling uninhabitable houses in Kolaka and Kolaka Utara regencies have their respective responsibilities which have been decided together. The regional government prepares the budget through the APBD and the Housing and Settlements Agency as the executor and the person in charge of the program. The village / kelurahan government is involved in data collection and verification of uninhabitable houses. The private sector is involved in the supply of building materials and the community participates in the form of willingness to become labor and readiness to provide materials (wood, sand, etc.).

In the results of the study revealed in the handling of uninhabitable houses in Kolaka and North Kolaka districts, the local government emphasized more on the direction function while the implementation was carried out by the Facilitator Team and the community. The government has become a catalyst and motivator to mobilize the public and the private sector to participate in handling uninhabitable homes. The magnitude of government power does not later become dominant, but the government's power is directed at how to build interaction with the private sector and the community to utilize their potential to overcome the problems faced in decent housing services.

\section{Commitment to goals}

The last phase in collaborative governance is commitment to goals. This phase illustrates the recognition of actors involved in collaboration to be responsible for solving public problems. In this case, actors who collaborate to remain in the same vision and mission to achieve the goals of collaboration.

Based on the results of the study, the handling of uninhabitable houses in Kolaka and North Kolaka regencies was carried out through a roof, floor and wall surgery program (ALADIN) and a stimulant housing assistance program (BSPS). In the implementation of these programs, the Housing and Settlements Agency collaborates with the private sector and the community. This collaboration requires strong commitment from each actor both institutionally and individually.

A form of commitment in handling uninhabitable housing in Kolaka and Kolaka Utara Districts, implementing assistance with a participatory approach. This participatory approach is considered to be the basic essence in articulating people's aspirations in realizing a decent house. The manifestation of the government's commitment in handling unlivable houses is that the Kolaka Regency and North Kolaka governments are shown through administrative and financial responsibilities through the APBD. In addition, the government also plays a role in fostering the target groups and determining program evaluation by considering the support and constraints of the surrounding environment

Meanwhile, the commitment of the business community and society in collaboration is characterized by implementing agreements that have been decided in formal and informal meetings with the government in the form of support for resources in the form of non-material rock. The business world is encouraged to have a concern for the development 
and community of Kolaka by setting aside a portion of the profits gained while investing in the area.

Based on this, the collaborative governance process in handling uninhabitable houses in Kolaka and Kolaka Utara regencies can be described as follows;

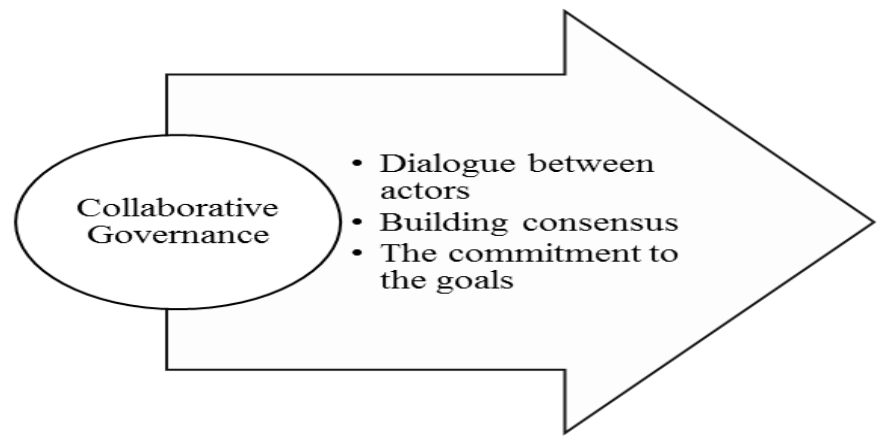

Figure: Collaborative Governance Process in Unworthy Home Handling Occupied in Kolaka Regency and North Kolaka (Processed, 2018)

The characteristics of collaborative governance in handling uninhabitable houses in Kolaka and North Kolaka are that collaboration is not always based on juridical legitimacy as a formal basis. But collaboration can take place in a non-formal framework. Collaborative governance with formal agreements is characterized by the existence of formal organizations and written agreements with the sharing of resource responsibilities both realized and not realized. While collaboration governance in the non-formal framework was built based on commitment in resource development. The commitment is related to a common desire to help the poor in creating livable and health-friendly homes.

\section{Factors Affecting Collaborative Governance in Handling Uuninhabitable Houses}

Handling Based on the findings of the study, formulated factors that influence collaborative governance in handling uninhabitable houses in Kolaka and Kolaka Utara regencies are:

a) Leadership: Leadership is an important variable in implementing collaboration. The role of leadership in collaborative governance is to assist stakeholders in finding solutions, designing strategies to solve problems by building synergies between both long-term and short-term parties.

b) Communication: Communication is the key to successful collaboration. Communication involves the delivery of information, ideas and opinions to bring together mutual understanding in achieving the mission and purpose of collaboration.

c) Commitment: Commitment involves the attitudes of actors that reflect determination and responsibility for ongoing collaboration. High commitment encourages parties involved in collaboration to have a responsibility to cooperate in solving public problems. d) Vision Equality: One of the main elements in building collaboration is the common goal and vision. The existence of the same vision will encourage the unification of the direction of action and shared views of the parties involved in the collaboration.

e) Bureaucratic Structure: The bureaucratic structure in collaboration involves the authority, responsibility and coordination mechanism between actors. Bureaucratic structures cannot be hierarchical and monopolistic by one party in collaborative collaboration. All actors have the same position in decision making.

\section{Conclusion}

Based on the discussion and research results, the authors formulated the following conclusions:

1. The process of collaborative governance in handling uninhabitable housing in Kolaka and North Kolaka Districts is carried out in a formal and non-formal framework. This collaboration occurs because of the limited resources owned by the government in realizing a habitable house while the number of uninhabitable houses is increasing. The process of collaborative governance begins with (1) dialogue between actors, (2) building consensus, and (3) commitment to goals.

2. Factors that influence collaborative governance in the handling of uninhabitable houses in Kolaka and North Kolaka District are: (a) leadership, (b) commitment, (c) similar vision, and (d) bureaucratic structure.

\section{References}

[1] Ansell, Chris and Alison Gash. 2007. Collaborative Governanance in Theory and Practice, Journal of Public Administration Research and Theory, Berkeley: University of Californi

[2] Budiharjo, Eko. 1998. Masalah Arsitektur Perumahan Perkotaan. Gadjah Mada University Press, Yogyakarta

[3] Bryson, John M., Barbara C. Crosby dan Melissa M. Stone. 2006. "The Design and Implementation of Cross-Sector Collaborations: Propositions from Literature". Public Administration Review 66(Special Issue): 44-55.

[4] Choi, Taehyon. 2014. Revisiting the Relevance of Collaborative Governance to Korean Public Administration. The Korean Journal of Policy Studies, Vol. 29, No. 2 (2014), pp. 21-41.

[5] Dwiyanto, Agus. 2010. Manajemen Pelayanan Publik: Peduli, Inklusif dan Kolaboratif. Yogyakarat. Gadjah Mada University Press.

[6] Huberman, dan Miles, 2014. Analisis Data Kualitatif, Jakarta: UniversitasIndonesia

[7] Kozuch, Barbara, Katarzyna SienkiewiczMalyjurek, 2016. Key Factors Of 
Organisational Collaboration In The Public Sector and Their Strength. International Journal of Contemporary Management Volume 15 (2016) Number 3, s. 123-144 www.ejournals.eu/ijcm

[8] Sabaruddin Abdul, 2015. Manajemen Kolaborasi dalam Pelayanan Publik, Yogyakarta: Graha Ilmu, 2015

[9] Syarief, Zulfie, 2000. Kebijakan Pemerintah Dibidang Perumahan dan Permukiman Bagi Masyarakat Berpendapat Rendah. USU Pres, Medan.

[10] Thomson, Ann Marie and James L. Perry. 2006. Collaboration Processes: Inside The Black Box. Public Administration Review. 66 (s1). 20-32.

[11] Wijaya, Doni Wahyu. 2016. Perencanaan Penanganan Kawasan Permukiman Kumuh. Studi Penentuan Kawasan Prioritas Untuk Peningkatan Kualitas Infrastruktur Pada Kawasan Permukiman Kumuh di Kota Malang. Jurnal Ilmiah Administrasi Publik (JIAP) FIA Universitas Brawijaya. Vol. 2. No.1 pp 1.10. 